\title{
A INOVAÇÃO TECNOLÓGICA COMO ALICERCE PARA O CRESCIMENTO ECONÔMICO BRASILEIRO PÓS-PANDEMIA
}

Quando nos deparamos com um evento tão inusitado e inesperado como a pandemia do COVID 19, ficamos perplexos e de certa forma paralisados. No entanto, o imobilismo nunca será a melhor alternativa como postura, mesmo em um ambiente momentâneo de total incerteza quanto ao melhor antídoto para um cenário ameaçador e com uma abrangência global.

Avaliando as alternativas de reação, no âmbito qualitativo, a inovação na aplicação da tecnologia tornou-se o recurso mais efetivo para a recuperação do crescimento econômico brasileiro. Inicialmente no cenário educacional, tudo o que era planejado de há muito para o ensino assistido pela tecnologia, tornou-se mandatório e intransferível, do dia para a noite, e o plano de mitigação do dano foi aplicado com toda intensidade, mobilizando as empresas de tecnologia com as suas plataformas educacionais, bem como o imediato e ágil aprendizado e aplicação dos docentes e discentes.

O mundo do conhecimento nunca esteve tão conectado e tão estreito, entre as instituições de ensino, institutos de pesquisa e a tão reclamada integração escola e empresa, aconteceu como em um passe de mágica e o ciclo virtuoso do conhecimento, ao meu ver, nunca foi tão acelerado e intenso. Simplesmente as barreiras físicas foram rompidas e passamos a ocupar, no mundo on-line, vários lugares no espaço e ao mesmo tempo. Nunca nos integramos tão rapidamente e com tanto foco na busca do conhecimento compartilhado, e como exemplo inequívoco da nossa necessidade de aprender, pesquisar e aplicar, vide a disponibilidade em tempo, até então inimaginável, da vacina, cuja aplicação iniciou-se em 08/12/2020 no Reino Unido.

Com o exemplo acima interligamos o campo da educação e pesquisa com o ambiente empresarial. Neste momento, compartilhando com um engenheiro responsável pela área de lançamento de produtos novos de uma grande multinacional do segmento automotivo no Brasil e América do Sul; ele relata que em março/2020, com o início do isolamento social e home-office, a primeira reação da empresa foi de adiar os projetos por um período de dois anos.

Ledo engano, pois rapidamente observou-se, como no campo da educação, que a inovação na aplicação da tecnologia, até então já disponível, mas sempre utilizada com limitações; seria o atalho para a recuperação econômica e os projetos foram mantidos conforme o seu cronograma original, com os novos produtos lançados e as fábricas preparadas, tão rapidamente e eficazmente, equivalente mesmo ao passado, com o presencial predominando; pois os resultados de custo, prazo e qualidade foram assegurados, e o aprendizado da equipe de projetos, com as metodologias ágeis e com uso intenso da tecnologia, nunca havia sido tão elevado.

Esta é a máxima da própria história da humanidade, pois nos momentos de crise é que nos superamos e atingimos níveis de desempenho classificados como superiores.

Avaliando o cenário atual, no encerramento de 2020, no âmbito quantitativo, pode-se verificar que a confiança do empresário e do consumidor mostram reação positiva; a 
atividade econômica seguiu em recuperação no $3^{\circ}$ trimestre; o índice Bovespa mostra forte recuperação posicionando-se nos 114.000 pontos; a projeção para o PIB brasileiro desenha um cenário menos negativo; taxa de câmbio deve se manter em patamar mais desvalorizado nos próximos anos (5,00 R \$US $\$$ em 2021); o juro básico buscará novas mínimas históricas (taxa SELIC 3,00\% em 2021); e inflação esperada abaixo da meta em $2021(3,5 \%)$.

Complementando as observações anteriores, visando ainda a continuidade do desenvolvimento econômico brasileiro no pós-pandemia, de maneira planejada e contínua, recomenda-se a adoção de uma gradativa evolução digital, através da continuidade da "cultura tecnológica", ora em curso, independentemente do nível de investimento, face a escassez atual de recursos. Para tal, os modelos de maturidade digital existentes oferecem a possibilidade de monitoramento e controle da implantação dos processos de transformação digital, mantendo a empresa em um rumo para atingir esse objetivo chave, cujo fundamento deve ser o processo de melhoria contínua, com a eliminação sistemática de desperdícios, avaliação permanente dos riscos ao negócio, proporcionado maior produtividade e competitividade.

Não podemos esquecer que essa revolução será feita "pelas pessoas e para as pessoas", sendo indispensável o desenvolvimento de novos pesquisadores interessados no tema de promoção da aceleração em resultados das empresas com foco na tecnologia digital.

Em síntese, uma sociedade mobilizada e com uma postura empreendedora, que prioriza o "saber, fazer e ser"; de forma resoluta e pró ativa, com a visão e responsabilidade pelo coletivo, valorizando a educação e o conhecimento compartilhado, teremos sem dúvida, pelo emprego da tecnologia digital e valorização dos recursos, cada vez mais escassos, um processo, mesmo que gradual, mas constante, de uma recuperação permanente e evolutiva da nossa economia, no pós-pandemia, mas não somente......

\section{Gilson Paula Lopes de Souza, MSc. Eng.}

Graduado em Engenharia Industrial Mecânica e em Engenharia de Higiene e Segurança pela FEI com MBA em Gestão Empresarial pela FGV e Mestre em Economia e Administração pela Universidade de Taubaté

Superintendente do IQA (Instituto da Qualidade Automotiva) e Fundador do IDExp (Instituto para o Desenvolvimento da Experiência)

Professor da FAE Centro Universitário e Empreendedor nas áreas de serviços de hotelaria e panificação 